\title{
Chapter 8: Regionalism and Economic Development: Achieving an Efficient Framework
}

\section{Andrew Beer}

\section{Introduction}

Economic development remains an aspiration of governments across Australia at the national, state and local levels. Both communities and governments seek growth with respect to their population, gross regional product, average income and the quality and quantity of their infrastructure. The impetus for economic development has, in large measure, dominated Australian politics and society over the last two decades, contributing to the reform of labour markets, the amalgamation and restructuring of local governments, changes to education and higher education, shifts within the public sector and a recasting of immigration. Central governments have been a major catalyst for economic growth, with the federal government in particular pushing for change in order to lift gross national product. Initiatives such as the National Competition Policy and WorkChoices legislation have sought to achieve microeconomic reform as a mechanism for delivering a more competitive position within the global economy. State and territory governments have also awarded priority to policies intended to achieve economic growth. Across the jurisdictions, there has been an emphasis on achieving 'AAA' credit ratings (Spoehr 2005) as a way of demonstrating business credentials and in some instances governments have implemented innovation strategies - such as Queensland's 'Smart State' program - as a way of enhancing their long term competitiveness.

While economic development has been an important driver of policy, the programs and actions of government have largely ignored regional impacts. The focus on the national economy or the state economy per se has given scant attention to the distribution of growth opportunities at the regional or local level. This has meant that the gap between prosperous regions and those that struggle has widened (Baum et al 2005), and that insufficient attention has been paid to the development of an adequate infrastructure for economic development at the local or regional scale (Beer et al 2003).

This chapter considers the current state of regional economic development in Australia, drawing attention to significant shortcomings in current structures. The chapter then draws upon the example of the responses of government to the loss of employment in the automotive industry in Adelaide during 2004, to 
illustrate the adverse impact of policy responses developed and implemented at an inappropriate scale. Finally, the chapter outlines some ideas on how a far stronger system for local or regional economic development could be implemented, and the benefits of such a system for both vulnerable communities and the national economy.

\section{Regional development in Australia: small scale, fragmented and non-metropolitan}

Regional development is an avowed aspiration of governments in Australia, but it is a goal that is often inadequately funded and of lesser priority in the long term. Regional development is not as prominent in the agendas of state governments as health and education, and, while governments recognise the need to pay attention to non-metropolitan issues, their engagement tends to be piecemeal and opportunistic rather than strategic and comprehensive. The small-scale nature of political engagement with regional issues engenders substantial challenges at a policy level, as policy debates are dominated by portfolios and Ministers with the most substantial budgets and influence within Cabinet. This section of this chapter considers the broad challenges confronting regional development in Australia, focussing in particular on the issues of fragmentation, the small scale of regional development efforts and the practice of defining regional issues as non-metropolitan issues.

\section{A fragmented framework for regional development}

Fragmentation in responsibility for regional development presents a major challenge for the practice of economic development in Australia. Fragmentation is evident in a number of ways: first, responsibilities for regional development are commonly distributed between the federal, state and local governments and it is common to see all three tiers of government engaged in regional development activities in any locality (see Beer, Maude and Pritchard 2003, p. 45). There is fragmentation also on a territorial basis with each State and Territory largely shaping the institutional architecture for regional development via their own agencies, the requirements they place on local government and through their funding policies (Beer and Maude 1997, 2002). There is, therefore, no uniformity across the States and Territories, and while there are common elements to the practice of regional development in Australia (Beer, Haughton and Maude 2003), there are also significant differences (Beer and Maude 2002).

As a number of academics and pundits have argued, the Federal Government is probably the only tier of government in Australia with the necessary resources to sustain a coherent and viable program of local or regional economic development (Logan 1978; Beer 2000). As the collector of $75 \%$ of public sector revenues it has greater financial capacity than either state or local governments. But federal governments have long shied away from an explicit involvement in 
formal regional development initiatives. Throughout the 1960s an Inter-Departmental Committee sat for eight years considering whether the Federal Government should act to promote decentralisation of people and economic activity. There was a brief flurry of activity in the early 1970s under the Whitlam Labor Governments, and then virtually nothing for almost 20 years. The Keating Government's Regional Development Program was hastily jettisoned by the newly-elected Howard Coalition Government, because it considered it had no constitutional role in the area, and that federal involvement would result in overlap and duplication with state and local government efforts. In the year 2000 the Howard Government re-engaged with local and regional development issues - admittedly at an initially modest level - via the Regional Solutions Program. More recently, the Federal Government has promoted regional issues through the reformulated Bureau of Transport and Regional Economics, the establishment of the Sustainable Regions Program focussed on 10 regions across Australia, and the Regional Partnerships Program.

While the Howard Coalition Government has not formally enunciated a major regional development program, it has intervened in the functioning of regional economies in many ways. For example, drought relief is a major regional intervention, as are the arrangements for guaranteeing the quality of telecommunications infrastructure in 'the bush' after the full privatisation of Telstra. Other research (Beer, Haughton and Maude 2003) has shown that Federal funding - from a variety of sources - typically makes up 40 per cent of the budgets of regional development bodies. And while this contribution to regional development efforts is welcome, regional development practitioners are only too aware that funding priorities are established centrally, not locally. Area Consultative Committees (ACCs) are an important part of the Federal Government's engagement with regions. ACCs were originally established as labour market organisations, but have been gradually transformed and refocussed on regional development issues, broadly defined. ACCs can be a source of funding for other regional development bodies and are often perceived to reflect the political interests of the government rather than genuinely reflecting the needs and interests of local community. Importantly, ACCs have not been part of a wider political project by the Australian Government - say, comparable with Cities Commission or the Department of Urban and Regional Development - and therefore their engagement with regional issues has been disjointed.

State governments are probably the most visible participants in regional economic development, and in aggregate would make the largest investment in encouraging growth locally. State governments are substantial investors in the infrastructure and services that sustain economic activity in metropolitan and non-metropolitan regions. Many state governments have a long history of involvement in formal regional development initiatives and in the immediate post-War period decentralisation programs were favoured. In line with the growth pole theory 
of the time, state governments used tax breaks and financial incentives in an attempt to create growth centres. Paul Collits (1995) has suggested that the period 1965 to 1975 was the high water mark for these initiatives, and this reflected the preference for dispersed development in Australia, recognition of the rising costs associated with the growth of Australia's biggest cities, evidence that the rural population was in decline, and the strength of the Country Party. Significantly, the regional development policies of state governments have continued to reflect the decentralisation debate, despite the demise of growth pole theory within the regional economic development literature and the rise of new dynamics within national and global economy. Many states continue to promote regional development within non-metropolitan regions, with South Australia, Western Australia and NSW essentially funding regional development boards outside the capital cities only.

Most local governments have some formal role in economic development activities, though participation varies considerably by state and location. Local governments have been the primary agents for economic development in Victoria since the mid-1990s, while local governments in Queensland have always played a much broader role within their communities than elsewhere in Australia. Their participation in the provision of major infrastructure - such as water supply, roads and electricity - has given them a greater capacity to influence growth. Local government remains the smallest and poorest tier of government in Australia and its circumstances are worsening (Hawker Report 2003). Over the last two decades, the real value of financial support to local government from the Federal Government has fallen - as has state financial support in most jurisdictions - while the tasks required of local governments by the other tiers of government have grown. Despite these pressures, local governments have not shied away from promoting their region or local economy. Many provide cash incentives or infrastructure to attract firms, and the majority would employ at least one staff member with responsibilities for economic development. In some places - notably Victoria - there are large Economic Development Units within individual local governments. While there is considerable variation around Australia, it is common for them to join state governments in funding regional development agencies, Business Enterprise Centres and or initiatives. Often they host special events designed to draw in tourists and will market their region nationally and internationally. It is worth noting that the national awards in local government explicitly recognise the role of local government in working for economic development. In 2004, Burnie City Council was recognised for its role in revitalising the city's airport and developing adjacent land as an industrial estate, while the town of Cressy in Tasmania's central highlands was recognised in 2005 for its 'Troutarama' festival.

It is important to acknowledge, from the discussion above, that responsibility for regional development in Australia is divided across the three tiers of 
government and that each - to a greater or lesser degree - has an equivocal attitude to the development of regions. For central governments (state and federal) there is a strong imperative to be perceived to be delivering real outcomes for regions, but this does not necessarily translate into a systematic engagement with regional development. Collits (2003) has noted the 'tyranny of the announceable' within regional development, with governments favouring regional initiatives that have a high media profile, a short time-frame and limited impact on the budget, over those policy measures that attract less public interest but are more likely to deliver growth in the long-term. Local governments are too often an ineffective participant in regional development because their resources are limited and their responsibilities wide-ranging. Overall, the very structure of Australian federalism makes the achievement of an efficient framework for regional economic development difficult. Financial power is concentrated in the Australian Government, constitutional power is held by state and territory governments, while local government has, in large measure, been left to 'muddle through' as best it can.

\section{Scale and regional development}

One of the challenges for regional development in Australia is the small scale of policy interventions. Over the last 20 years, Labor and Coalition Federal Governments have transformed the Australian economy but they have relied upon policy levers that operate at the level of the whole economy to achieve their objectives. These have included: the floating of the Australian economy; lifting of control on exchange rates; a reliance on monetary policy to regulate the economy; national competition policy; micro economic reform; and de-regulation of the labour market. Australian governments have not embraced direct interventions in the economy - at either a national or regional level - via wholesale investment in infrastructure or wide-ranging business development programs. The failure to engage in these measures has had significant consequences, as reflected in the fact that, by 2006, Australia's exports were retarded by a shortage of port infrastructure. At the same time, a skills shortage has emerged, largely as a result of inadequate programs for skills development and enhancement. Other nations faced with the challenge of reforming their economy have teamed conventional national policy measures with explicit regional development initiatives. In the Republic of Ireland, for example, economic reform through the 1990s was matched by substantial investment in transport infrastructure, environmental programs and labour market training (MacSharry et al 2000). The combination of national policy change and strategic investment in regional development catapulted development in the Republic of Ireland, such that in 1990 Ireland's per capita income stood at less than $80 \%$ of the European Union average, but by 2006 incomes in the Republic of Ireland exceeded the EU mean. 
The absence of large scale interventions in the economies of regions significantly reduces the ability of regional development agencies to achieve substantial outcomes. Other research has shown (Beer, Haughton and Maude 2003) that regional development agencies in Australia largely play a facilitative role: assisting business projects pass through the development approval process; lobbying for infrastructure; co-ordinating economic development strategies; networking with businesses and other development bodies and promoting tourism. By contrast, regional development agencies in England and the United States have, on average, much larger budgets and engage in a different range of activities (Beer, Haughton and Maude 2003). In the US, agencies are often locally funded, have a strong business orientation and report very high levels of achievement (Beer, Haughton and Maude 2003). In England, regional development bodies are much more likely to engage in state-of-the-art economic development practices - such as business incubators, supply chain associations, technology diffusion strategies etc. - and in large part this reflects their more generous funding.

It is important to acknowledge that governments across Australia often offer up small-scale policy solutions to the large-scale problems confronting regions. In part this is justified by the 'self help' philosophy embedded within neo-liberalism (Gray and Lawrence 2000), but it also reflects a new, and cynical, set of tendencies within government to be spatially selective (Jones 1997) and to reinforce the success of prosperous regions while ignoring the demise of the less fortunate. As will be discussed in the case study below, governments increasingly have a tendency to offer up politically expedient, short-term, responses to regional economic crises, while ignoring the long term implications and the strategies needed to provide solutions into the future.

\section{Regions: an ex-urban phenomenon?}

In Australia, regional development is usually equated with non-metropolitan or rural development. It is as if regions start at the metropolitan boundary - or to view this phenomenon in another way, it is as if regions exist up to the edges of the capital cities and then disappear. Evidence of this trend can be seen in the Australian Government's most recent regional policy statement, by the former Deputy Prime Minister and Minister for Transport and Regional Services, John Sharpe. In his foreword to this policy statement, the Deputy Prime Minister noted that:

A thriving Australia needs growing and vibrant regions. The Federal Government is committed to ensuring a strong and resilient regional Australia now and in the future - supporting community ideas, leadership and development. We are committed to a regional Australia recognised by us all for its contribution to our great nation. 
The Liberal-National Government believes that Australia needs strong and prosperous regions - now and into the future. We want regional Australia recognised and respected by all Australians for its enormous contribution to the nation's identity and to our national economic and social wellbeing.

Over the past five and a half years we have done much to rebuild country Australia and today there are real signs of better times. Nonetheless, as we look to the future, much remains to be done. (Anderson, nd, p. 2).

A number of assumptions and values are embedded in this pronouncement. First, there is a clear link in the Deputy Prime Minister's statement between 'regional Australia' and country Australia. Second, there is an overt political dimension to the policy document, with the 'Liberal-National Government' explicitly canvassed rather than more inclusive language around the role of the Australian Government. Third, and relevant to the discussion in the section above, the Deputy Prime Minister's foreword establishes the rhetoric of regional development - including recognition of the symbolic importance of 'regional Australia', the need to support communities ideas and build leadership, but offers few substantive programs of assistance.

Similar spatial biases are evident in the formal regional policies of state governments, with an emphasis on non-metropolitan regions and, in large measure, an absence of discussion about the development of metropolitan regions. The exclusion of cities from the discussion of regions in Australia has profound implications, and, perhaps counter-intuitively, in the long term, it disadvantages the communities that might be seen to benefit from this assistance. The focus on non-metropolitan regions ensures there is no political consensus around the need for a spatial development strategy or a comprehensive regional development framework. At a political level, both sides of politics perceive regional development policy as serving the interests of National Party or Liberal Party electorates, while the metropolitan corollary - urban policy - is viewed as serving the immediate electoral interests of the Labor Party. In both cases, the perception that locationally-focussed policy interventions equate to 'pork barrelling' (McFarlane 2002) weakens the case for their continuation in the long term and contributes to disruption when governments change. At a policy level, the alignment of political interests with regional policy weakens the case for large scale programs in debates with Treasury or other central government agencies. It makes it more difficult to justify larger programs and creates an apparently insurmountable hurdle to arguments that systematic policy interventions are required.

At a more immediate level, it is often the case that regions - such as large peri-urban local governments - are eligible for funding for half their jurisdiction 
on the grounds that they are defined as rural, while the other half is seen as metropolitan and is therefore excluded from financial support.

\section{Regional policies? Mismatch in the scale of delivery and the scale of need in responding to job losses in the automotive industry}

The discussion so far has focussed on the broad dimensions of regional development in Australia and the structural and institutional processes that have made the system both inefficient and, on occasion, ineffective. It has been argued that the Australian system of federalism, in conjunction with neo-liberal policy instruments, has resulted in a fragmented approach to regional development, and one which is dominated by the politics of regionalism rather than a systematic concern with addressing spatial inequalities and improving the quality of life of all Australians. This section examines government responses to the loss of jobs at Mitsubishi Motors Australia Ltd (MMAL) in 2004 and uses this example to illustrate the issues of fragmentation, scale and the inadequate conceptualisation of regions canvassed above.

\section{Employment loss at Mitsubishi Motors Australia: a regional crisis?}

In April 2004, Australia's Prime Minister John Howard - flanked by South Australian Premier Mike Rann and Mr Tom Phillips, the serving CEO of Mitsubishi Motors Australia Limited (MMAL) - announced that the Lonsdale plant of MMAL would be closed with a loss of 700 jobs, with a further 400 voluntary redundancies from MMAL's Tonsley Park assembly plant. The factory had been in operation since the mid 1960s and performed a number of roles, including a foundry where engine blocks were cast, as well as hosting the assembly of some components, such as brake knuckles. The Tonsley Park plant has remained a site for vehicle assembly, but functions such as inventory and upholstery manufacture have been further outsourced.

The loss of just over 1,100 jobs in the southern part of metropolitan Adelaide was recognised as a major setback to the regional economy. The Federal Government responded by announcing a $\$ 45$ million assistance package for the region - called the Structural Adjustment Fund (SAF) - as well as enhanced employment assistance for retrenched workers. This assistance was to be delivered via the Jobs Network, Australia's network of federally-funded labour market providers. In addition, the South Australian Government committed \$10 million of assistance to displaced workers, mainly in the form of enhanced access to services. The loss of employment from MMAL in 2004 can be seen to be part of the longer term restructuring of the automobile industry, and manufacturing more generally, in Australia (House of Representatives Inquiry into the Automotive Component Manufacturing Sector, 2006). In the mid-1970s 
manufacturing employment accounted for $25 \%$ of the workforce but by 2001 it had declined to $12 \%$ of the labour force, even though the value of production had increased (Forster 2003). Where once car-making plants could be found in all state capitals except Perth, by the year 2000 motor vehicle production had consolidated into a limited number of sites with Toyota and Ford assembling vehicles in Melbourne, Mitsubishi and General Motors Holden building cars in Adelaide, and General Motors Holden building engines in Melbourne.

The southern region of Adelaide - defined as the jurisdictions of the City of Onkaparinga and the City of Marion - was perceived to be at risk economically as a consequence of the MMAL job losses. Its potential vulnerability reflected a number of structural factors, including the fact that the region has a relatively unskilled and under-qualified workforce (City of Marion and City of Onkapringa 2006); regional incomes are lower than the national average (ABS 2001); and a significant proportion of the workforce is employed outside the region. The further loss of local employment had the potential to undermine the viability of the region's small businesses. More specifically, the workforce being made redundant was mature and tended to be concentrated in neighbourhoods close to the MMAL factories. There was, therefore, a real prospect that those who left Mitsubishi would not find paid employment and that the consequences of employment loss would be concentrated in a relatively small area. In addition, the region as a whole has lagged behind the expansion of manufacturing - and especially advanced manufacturing - in other parts of the metropolitan area, as the majority of new manufacturing enterprises have established in northern Adelaide. Businesses within the southern region of Adelaide tend to be small-scale and relatively mature (Kearins 2002). The Mobil (Exxon) oil refinery at Lonsdale had closed two years previously with significant loss of employment; and the wine industry in the southern part of the City of Onkaparinga (Southern Vales/McLaren Vale) faltered in 2004 and 2005 as the national supply of grapes for wine production exceeded demand. Finally, it is worth noting that the southern region of Adelaide is relatively poorly served in terms of access to infrastructure, with transport, power and telecommunications of a poorer standard than its competitor regions.

\section{Regional responses}

The announcement of job losses from MMAL was accompanied by the establishment of a new institutional structure to deal with the consequences of the plant closure and employment loss. A new body was established - the South Australian Government Advisory Group - to provide the government with industry-relevant advice under the chairmanship of a former President of General Motors Japan. Four sub-committees were also established: 
- Lonsdale Facility Assets to advise on the best possible use of the vacated Lonsdale Plant;

- Outplacement Opportunities to provide guidance on labour market programs and issues;

- The Southern Suburbs Industry Development Working Group (SSIDWG) to assist with the further development of the southern region economy, and

- Tonsley Park Utilisation which was charged with identifiying strategies to ensure the on-going financial viability of MMAL's remaining factory.

From its inception, considerable importance was attached to the work of SSIDWG as it was the only sub-committee to involve representatives of the region and it had a mandate to shape a new future for the region. SSIDWG commenced meeting fortnightly in May 2004 and began to address an ambitious program of work including: planning for a Southern Summit to raise the profile of the challenges confronting the Southern Region; preparation of a regional economic development strategy that embraced the two council areas (The Blueprint for the Future); research into the availability of land for further industrial development; contact with businesses and other organisations interested in investing in southern Adelaide or in applying for money from the Structural Adjustment Fund (SAF); and planning for an Innovation Centre in the south.

SSIDWG's role needs to be viewed within the context of the broader processes of government, as well as the overall response to the closure of the Lonsdale plant. It is important to emphasise that the $\$ 45$ million of funds made available through the SAF was by far the most significant response to economic restructuring. Limited, or no, resources were committed by the State and Australian governments to other initiatives such as SSIDWG. This stands in stark contrast to policy responses in other regions - such as Birmingham, UK where governments have invested substantial resources in the institutions managing the processes of change at the regional level. The MG Rover Task Force, set up when MG Rover announced that it has entered administration, had $£ 175$ million allocated to deal with the impact of the MG Rover closure and to assist further modernisation and diversification of suppliers (MG Rover Task Force, July 2005).

The SAF was the most significant response by central governments to the loss of employment at MMAL, and we must recognise that it does not fit easily within contemporary paradigms of regional development (see, for example, OECD 2001; Rainnie 2004) because the program consisted of grants - effectively capital subsidies - to firms willing to invest in South Australia. The SAF supported firms that were able to make a 'business case' that the injection of additional capital would allow for the expansion of business and would result in a significant number of new jobs. Firms had to match the grant awarded to them and complete a substantial application which was assessed by the advisory group. Two issues 
are critical here: first, SAF monies were not targeted exclusively to the southern region of Adelaide; and, as Table 8.1 shows, more grants were awarded to firms outside the region as within southern Adelaide. In other words, the SAF was intended to assist firms within the South Australia region, rather than focus on southern Adelaide. This meant that approximately half the funding went to the booming northern Adelaide region.

In part this decision was justified on the basis that workers from the south would commute to the new opportunities in the north, but as other research (Beer et al 2006) has shown, many retrenched workers were reluctant to undertake such time-consuming journeys to work, with a number choosing to leave the formal labour force rather than seek work in the north. Second, grants of this nature are a relatively blunt policy instrument and one which has fallen out of favour in most developed economies (Haughton et al 2003). Commonly, subsidy programs of this nature do not achieve the employment outcomes forecast - and committed to - by businesses (Beer, Maude and Pritchard 2003) and the diverse firms able to take up these opportunities effectively precludes the targeting of those industries considered to have the best long term prospects. In this instance, as shown in Table 8.1, the single largest grant was awarded to a chicken processing plant (Ingham Processing) in northern Adelaide.

Table 8.1: Grants Awarded under the Structural Adjustment Fund

\begin{tabular}{lllr}
\hline Company & Amount & Location (in & Jobs created \\
\hline Redarc Electronics & $\$ 1.6$ million & Lonsdale (Southern) & 60 \\
Alloy Technologies International & $\$ 1.8$ million & Wingfield (Northern) & 100 \\
Resource Co & $\$ 3$ million & Lonsdale (Southern) & 120 \\
Cubic Pacific & $\$ 0.95$ million & Edinburgh Park & 75 \\
(Northern) & Lonsdale (Southern) & 140 \\
Fibrelogic Pty Ltd & $\$ 5.9$ million & Edinburgh Park & 245 \\
Ingham's Enterprises & $\$ 7$ million & (Northern) & 68 \\
Intercast and Forge & $\$ 2.5$ million & Wingfield (Northern) & $?$ \\
PBR Australia & $\$ 1.5$ million & Lonsdale (Southern) & 80 \\
Normanville Export Meatworks & $\$ 3.5$ million & South (Southern) & 73 \\
SAGE Group Holdings & $\$ 1$ million & Holden Hill & (Northern) \\
ScreenCheck Australia Pty Ltd & $\$ 500,000$ & Melrose Park & 22 \\
BD Farms Paris Creek Pty Ltd & $\$ 900,000$ & Adelaide Hills & 40 \\
True Life Creations & $\$ 1$ million & Adelaide city & 46 \\
Origin Energy Solar Pty Ltd & $\$ 2$ million & Regency Park & (North West) \\
Jumbo Vision International & $\$ 1.8$ million & Mawson Lakes & (Northern) \\
Inpak Foods & $\$ 2.1$ million & Royal Park (North & West) \\
\hline
\end{tabular}


Critically then, government responses to the loss of employment at MMAL included a high profile grant program from the Australian Government that was not targeted to the affected region, and which the evidence suggests is likely to be ineffective in the long term. The South Australian Government response was restricted and did not include ongoing measures to assist the adjustment of regional businesses. Local governments - the junior tier of government within Australian federalism (Troy and Stilwell 2000) - were left with responsibility for developing and implementing a more strategic approach to advancing the wellbeing of the southern region. SSIDWG emerged as an important avenue for local government to articulate its vision for the future of the region, as it adopted the roll of a 'clearinghouse' whereby ideas and issues were raised and tested against the opinions and attitudes of central government agencies. SSIDWG was the catalyst for a number of regional development strategies that attempted to present a new 'vision' for southern Adelaide and these are discussed in more detail in the section below.

The Australian Government chose to implement a Structural Adjustment fund that operated at the scale of all of South Australia. Effectively this decision saw the region affected by the redundancies as the entire state, and privileged that scale of intervention over a more tightly targeted intervention in the southern region. Critically then, the SAFSA allocated more monies to enterprises outside the southern region than within it. This outcome reflected both a neo-liberal ideology in which governments place priority on assisting private industry to expand in the wake of economic shocks, and an emphasis on market processes that operate on a wide geographic scale. It is quite possible that SAFSA funding would not have been fully allocated within the two year time period if had been restricted to the southern region. Instead, central governments would have been forced to think - more imaginatively - about other forms of assistance and support for the region. Such approaches could have included the provision of infrastructure that would have enhanced the competitive position of the region; comprehensive labour market training and education; and small business development programs. The approach adopted by the Australian Government assumed that workers displaced from MMAL would be willing and able to find employment in other regions, including northern metropolitan Adelaide. Other research (Beer et al 2006) challenges this assumption.

The strategic priorities of both the Australian Government and the Government of South Australia must be reviewed in order to understand the scale at which governments chose to act. For the Federal Government, the southern region of Adelaide is not a strategic priority as the nation's medium to long-term growth prospects are tied to mining and the expansion of knowledge-intensive industries along the eastern seaboard. The South Australian Government, also, had priorities that lay elsewhere. During the period of redundancies at MMAL the South Australian Government was bidding for, and won, a substantial expansion in 
its defence industries and was at the same time promoting the growth of mining in the northern part of the state. Indeed, the State government's priorities in the expansion of manufacturing capacity lay in northern Adelaide, in and around Edinburgh Park, where there was significant state government investment in road, rail and land development.

\section{Conclusion: can Australia achieve an efficient framework for regional development?}

Through this chapter I have argued that regional development in Australia is hampered by the outcomes of our system of federalism, by political ideologies grounded in neo-liberalism that are wary of direct interventions in regional economies, and by an emphasis on short-term political responses, rather than longer term strategic interventions. As the case study of the response to the loss of employment at MMAL has shown, governments often choose to act at scales that do not coincide with the scale of need: the closure of the Lonsdale plant and the loss of jobs at Tonsley Park generated challenges for the southern region of Adelaide, but the major response was directed to all of South Australia. This mismatch resulted in the leakage of a considerable percentage of assistance out of the region, often to localities where governments had other priorities. In large measure this failure of scale reflects a flawed understanding of regional issues and regional policies. In the case study presented here, the failure of either the Australian or State government to articulate regional policies that embraced both metropolitan and non-metropolitan regions meant there was no formal structure in place to serve as a mechanism for the delivery of assistance, and gave governments room to manoeuvre in directing assistance to where funding would best suit their political ends, rather than the real needs of affected regions.

Australian federalism lies at the heart of the failure to develop appropriate regional policies. As noted above, the Australian Government has the funding that would empower an effective regional development framework, the State and Territory governments have the constitutional power, and local governments have neither the funding or the power, but have the commitment needed to bring about change. As the discussion of the response to job losses at Mitsubishi Motors has shown, the division of powers between the three tiers of government contributes to a clouding of the lines of responsibility and accountability. While leader of the Opposition, Kim Beazley noted that:

buckpassing between Commonwealth and the States isn't a new problem. But it has reached absurd heights in recent years ...

John Howard's federalism has failed. Failed to tackle Australia's challenges. Failed to seize special opportunities. Failed to lay foundations for future prosperity (Beazley 2006, p.1). 
In a similar vein, the Business Council of Australia has described our federal system as 'chronically blurred and confused'. It would be false to expect that Australian federalism would operate more efficiently if Labor was in power nationally, because the fundamental tensions between the revenue raising powers of national government and the substantial expenditure and service provision responsibilities of state and territory governments would remain unchanged. State governments must also shoulder their share of the blame for the parlous state of regional policy in Australia. The new-style state populism pioneered by Bob Carr in NSW is dominated by slogans such as being 'tough on crime' and emphasises health and education expenditure over other fields. There is little scope for systematic and comprehensive regional economic development strategies - that would focus on non-metropolitan and metropolitan regions alike - within this political and policy framework.

Finally we should ask, is it possible to achieve an efficient framework for regional development in Australia? At a technical level the answer must be yes, we know that other nations have more rational and comprehensive approaches to regional development than that evident in Australia. We are also aware of the strategies and techniques that could deliver better economic development outcomes (see, for example, Beer, Haughton and Maude 2003) but such technical solutions are of little merit unless there is fundamental change within Australian federalism. We need a system of government that recognises the importance of regional development and that allocates resources and responsibilities appropriately. Until that time, Australia is likely to continue to experience the impact of partial and inadequate regional development policies.

\section{References}

Anderson, J. (undated), Stronger Regions: A Stronger Australia, Department of Transport and Regional Services, Canberra.

Australian Bureau of Statistics 2001, Census 2001, ABS, Canberra.

Beazley, K. 2006, 'Modern Federalism: Beyond States' Rights and States' Wrongs', Address to the Economic and Social Outlook Conference, Melbourne, November.

Beer, A. 2000, 'Regional Policy in Australia: Running out of Solutions?' Chapter 10 (pp 169-194) in Pritchard, B. and McManus, P. (ed.) Land of Discontent, University of New South Wales Press, Sydney.

Beer, A., F. Baum, H. Thomas, C. Lowry, C. Cutler, Guangyu Zhang, G. Jolley, A. Ziersch, F. Verity, C. MacDougall and L. Newman, 2006, 'An Evaluation of the Impact of Retrenchment At Mitsubishi Focussing on Affected Workers, Their Families and Communities: Implications for Human Services Policies and Practices', Department of Health, Adelaide, Unpublished. 
Beer, A., G. Haughton and A. Maude, 2003, Developing Locally: Lessons in Economic Development from Four Nations, Policy Press, Bristol.

Beer, A. and A. Maude, 1997, Effectiveness of State Frameworks for Local Economic Development, Local Government Association of South Australia, Adelaide.

2002, Local and Regional Economic Development Agencies in Australia, Local Government Association of South Australia, Adelaide.

Beer, A., A. Maude and B. Pritchard, 2003, Developing Australia's Regions: Theory and Practice, University of NSW Press, Sydney.

City of Marion and City of Onkaparinga 2006, Southern Region Economic Diversification Plan Draft.

Collits, P. 1995, 'Balanced State Development in NSW Policy Making - Past Glories and Future Prospects', Paper presented to the Australian and New Zealand Regional Science Association, Brisbane, December.

- 2003, 'The Tyranny of the Announceable', Paper presented to the Australian and New Zealand Regional Science Association, Fremantle, September.

Forster, C. 2003, Australian Cities, Continuity and Change, Second Edition, Oxford University Press, Melbourne.

Haughton, G., A. Beer and A. Maude, 2003, 'Understanding International Divergence and Convergence in Local and Regional Economic Development' in Beer, A. et al (eds) Developing Locally, Policy Press, Bristol, pp. 15-36.

House of Representatives, Standing Committee on Employment, Workplace Relations and Workforce Participation, $1^{\text {st }}$ May 2006.

House of Representatives Standing Committee on Economics, Finance and Public Administration (The Hawker Report) 2003, Rates and Taxes: Fair Shares for Responsible Local Government, The Parliament of the Commonwealth of Australia, Canberra.

Jones, M. 1997, 'Spatial selectivity of the state?' Environment and Planning A, 29, pp. 831-64.

Kearins, B. 2002, 'Exporting Locally: A Strategy for Regional Small Business Growth', Sustaining Regions, 2(1), pp. 17-28.

MacSharry, R., P. White, and J. O'Malley, 2000, The Making of the Celtic Tiger, Mercier Press, Cork.

McFarlane, D. 2002, 'Deputy Prime Minister Serves Up More Pork', The Australian, p. 3, 12 June.

MG Rover Task Force, 2005, 'Closure of MG Rover: Economic Impact Assessment', July, Birmingham. 
Federalism and Regionalism in Australia

OECD 2001, Best Practices in Local Economic Development, OECD, Paris.

Rainnie, A. and M. Grobelaar (eds) 2005, The New Regionalism, Ashgate,

Aldershot.

Spoehr, J. 2005, The State of South Australia, Wakefield Press, South Australia. 